\title{
US Congress fails to agree Zika virus funding before summer break
}

\author{
Michael McCarthy
}

Seattle

The US Congress adjourned for a seven week summer recess on 14 July without passing additional funding aimed at tackling the Zika virus outbreak, despite warnings from health officials that this would slow research into diagnostic tests and vaccines and hamper prevention efforts.

President Barack Obama requested \$1.9bn ( $£ 1.4 \mathrm{bn} ; € 1.7 \mathrm{bn})$ in emergency funding in late February, but Democrats in the Senate blocked a $\$ 1.1$ bn funding bill twice, after Republicans added provisions that the Democrats said were unacceptable.

These provisions included substantial cuts to other health programs, restrictions on funding for contraceptive services that targeted the non-profit reproductive health services organization Planned Parenthood, weakening of pesticide regulations, and the blocking of a ban on displaying the Confederate flag at military cemeteries. Republicans sought to deny federal funds to Planned Parenthood, which runs 650 women's clinics nationwide, because it has provided abortion services.

Both parties blamed the other for the stalemate. Senator John McCain, a Republican from Arizona, accused Democrats of engaging in partisan politics rather than fighting Zika. He said, "This shameful action represents nothing more than an election year stunt, and confirms everything the American people hate about Washington."

Senator Patty Murray, a Democrat from Washington state who had negotiated a bipartisan compromise bill that initially passed through the Senate, said that Republican leadership had acquiesced to the party's conservative Tea Party wing by demanding the provisions.

Murray said, "The Senate passed a strong, bipartisan down payment on that proposal — but instead of staying the bipartisan course, Republicans have unfortunately chosen to put their ideological battles against Planned Parenthood and women's health providers ahead of the health needs of women and children nationwide."

As at 13 July, the US Centers for Disease Control and Prevention had received reports of more than 1300 cases of Zika virus infection in the continental United States and Hawaii and more than 2900 cases in the US territories, primarily in Puerto Rico.

All the infections reported in the US have been acquired abroad or through sexual transmission with someone who had acquired the infection abroad, including one reported case of female to male transmission of the virus. All but 11 of cases reported in Puerto Rico have been acquired locally.

As at 7 July, nearly 650 cases of laboratory confirmed cases of Zika infection in pregnant women had been reported in the US and its territories, and there had been 16 live births or pregnancy losses with birth defects associated with Zika infection during pregnancy. The reported defects included microcephaly, calcium deposits in the brain indicating possible brain damage, absent or poorly formed brain structures, abnormal eye development, and other problems that have been associated with Zika virus infection. 